\title{
PENGEMBANGAN MULTIMEDIA PEMBELAJARAN INTERAKTIF KOMPETENSI DASAR PEMASANGAN SISTEM PENERANGAN DAN WIRING KELISTRIKAN DI SMK
}

\author{
Nopriyanti \\ Universitas Sriwijaya \\ nopriyanti_08@yahoo.co.id \\ Putu Sudira \\ Universitas Negeri Yogyakarta \\ putupanji@uny.ac.id
}

\begin{abstract}
Abstrak
Penelitian ini bertujuan untuk: (1) menghasilkan multimedia pembelajaran interaktif kompetensi dasar pemasangan sistem penerangan dan wiring kelistrikan; (2) mengetahui kualitas multimedia pembelajaran interaktif; dan (3) mengetahui efektifitas multimedia pembelajaran interaktif kompetensi dasar pemasangan sistem penerangan dan wiring kelistrikan pada kelas XI SMK bidang keahlian Teknik Kendaraan Ringan. Penelitian ini merupakan penelitian dan pengembangan. Validasi multimedia dilakukan oleh ahli materi dan ahli media. Subjek uji coba penelitian ini adalah 32 siswa kelas XI SMKN 2 Depok, Sleman, Yogyakarta bidang keahlian Teknik Kendaraan Ringan. Kesimpulan dari penelitian ini adalah: (1) produk multimedia pembelajaran interaktif kompetensi dasar pemasangan sistem penerangan dan wiring kelistrikan layak digunakan; (2) kualitas multimedia interaktif ini sangat baik, hasil penilaian ahli ditinjau dari pembelajaran 66 (baik), isi sebesar 54 (baik), aspek tampilan 97 (baik), dan program 50 (baik), sedangkan hasil dari penilaian peserta didik uji coba lapangan pada aspek pembelajaran1277 (sangat baik), isi 1195 (sangat baik), tampilan 1562 (sangat baik), dan pemograman 519 (sangat baik); (3) Produk multimedia pembelajaran interaktif kompetensi dasar pemasangan sistem penerangan dan wiring kelistrikan efektif meningkatkan hasil belajar siswa. Rata-rata penilaian hasil belajar siswa ketika pretest adalah 63,75 dengan nilai terendah 50 dan nilai tertinggi 75. Sedangkan rata-rata nilai posttest sebesar 78,75 dengan nilai terendah 65 dan nilai tertinggi 90.
\end{abstract}

Kata kunci: pengembangan, multimedia interaktif, sistem penerangan dan wiring kelistrikan

\section{DEVELOPING INTERACTIVE LEARNING MULTIMEDIA THE BASIC COMPETENCY IN INSTALLING LIGHTING AND ELECTRIC WIRING SYSTEMS AT VOCATIONAL SCHOOLS}

\begin{abstract}
This study aims to: (1) develop an interactive learning multimedia the basic competency in installing lighting and electric wiring system; (2) describe an the quality of the interactive learning multimedia; and (3) describe the effectiveness of the interactive learning multimedia the basic competency in installing lighting and electric wiring system for Grade XI students of the Light Vehicle Engineering expertise competency program at SMK. This was a research and development $(R \& D)$. The validation of the multimedia by a matterial expert and media expert. The tryout subjects in the study were 32 people Grade XI students of the Light Vehicle Engineering expertise competency program at SMKN 2 Depok. The conclusions of the study are as follows. (1) the interactive learning multimedia product for the basic competency in installing lighting and electric wiring systems is appropriate to be used for learning grade XI SMK. (2) the assessment of the material expert and media expert on instructional learning multimedia show that the learning aspect attain a score of 66 (good), the content aspect attains a score of 54 (good), the display aspect attains a score 97 (good) and the aspect attains a score of the 50 (good) while the students' assessment from the field tryout conducted
\end{abstract}


at SMK Negeri 2 Depok shows that the learning aspect attains a score of 1277 (very good), the content aspect attains a score of 1195 (very good), the display aspect attains a score of 1562 (very good), and the programming aspect attains a score of 519 (very good); (3) the developed product is effective to improve the student learning outcomes. This is indicated by the result of the pretest and posttest analysis. The Average assessment of learning outcomes when the pretest of 63,75, with the lowest score of 50 and a highest of 75 . While the average score posttest of 78,75 with the lowest score of 65 and the highest score of 90.

Keywords: development, interactive learning multimedia, lighting and electric wiring systems

\section{PENDAHULUAN}

Pendidikan kejuruan sangat berperan dalam mempersiapkan siswa untuk dapat bekerja atau memasuki dunia kerja sesuai dengan bidang keahliannya. Salah satu yang harus diperhatikan dalam pendidikan kejuruan adalah kebutuhan pasar (market driven). Firdausi dan Barnawi (2011, p. 20) menjelaskan bahwa pendidikan kejuruan harus berorientasi pada kebutuhan pasar (dunia kerja) atau demand-driven, pendidikan kejuruan tersebut harus selalu mengikuti perkembangan teknologi terbaru, pembelajarannya harus diarahkan pada peningkatan kualitas keterampilan (skill), dan penilaian kemampuan peserta didik harus mengacu pada standar dunia kerja. Kompetensi Keahlian Teknik Kendaraan Ringan (TKR) merupakan salah satu kompetensi keahlian yang ada di SMK Negeri 2 Depok Sleman. Tujuan umum dari kompetensi adalah mempersiapkan peserta didik terutama untuk bekerja dalam bidang tertentu. Secara khusus tujuan kompetensi ini adalah membekali peserta didik dengan keterampilan, pengetahuan dan sikap agar memiliki kompetensi yang bersaing pada dunia kerja.

Keberhasilan SMK dalam menciptakan lulusan yang berkompeten tidak luput dari peran guru dan fasilitas yang ada. Proses pembelajaran juga memegang peranan penting dalam menghasilkan lulusan yang kompeten dan profesional. Faktor penentu keberhasilan dalam proses pembelajaran tersebut diantaranya adalah penggunaan media. Keterbatasan media membuat pelaksanaan pembelajaran yang dilakukan kurang optimal. Selain itu, keterbatasan guru dalam memanfaatkan dan mengembangkan media pembelajaran ini masih kurang. Proses pembelajaran kompetensi dasar sistem penerangan dan wiring kelistrikan membutuhkan pemahamaan yang kuat baik teori maupun praktik. Teori yang disampaikan oleh guru terkadang membuat siswa kurang memahami secara maksimal karena penyampaian materi oleh guru selama ini masih berorentasi pada pembelajaran yang berpusat pada guru (teacher centered). Hal inilah yang menjadi permasalahan klasik pembelajaran kompetensi dasar ini.

Berdasarkan observasi dan wawancara dengan guru SMK Negeri 2 Depok diperoleh hasil antara lain: (1) hasil belajar siswa pada proses pembelajaran kompetensi dasar memasang sistem penerangan dan wiring kelistrikan masih rendah; (2) sebagian besar siswa masih kesulitan memahami materi sistem penerangan; (3) metode pembelajaran yang digunakan masih kurang tepat; (4) cara penyampaiaan materi masih berorientasi pada pendekatan pembelajaran teacher centered; (5) penggunaaan media pada proses penyampaian materi sistem penerangan dan wiring kelistrikan ini masih kurang; (6) belum tersedianya multimedia pembelajaran yang bersifat interaktif pada kompetensi dasar sistem penerangan kendaraan dan wiring kelistrikan.

Upaya perbaikan yang dilakukan agar proses pembelajaran dapat berjalan baik dan optimal adalah dengan cara meningkatkan kualitas pembelajaran. Hal yang dapat dilakukan yaitu memanfaatkan media yang sesuai, inovatif dan interaktif dapat mempengaruhi peningkatan kualitas proses pembelajaran. Hamalik (1994, p.12) menjelaskan media pembelajaran adalah alat, metoda dan teknik yang digunakan dalam rangka lebih mengefektifkan komunikasi dan interaksi antara pengajar dan siswa dalam proses pendidikan dan pengajaran di sekolah. Media pembelajaran juga merupakan unsur yang paling penting dalam proses pembelajaran 
karena mengandung informasi dan pesan pembelajaran. Hasil penelitian dari Computer Technology Research (CTR) menunjukan bahwa seorang hanya dapat mengingat apa yang dilihatnya sebesar 20\%,30\% dari yang didengarnya, $50 \%$ dari yang didengar dan dilihatnya, dan $80 \%$ dari yang didengar, dilihat, dan dikerjakannya secara simultan. Hal ini bearti bahwa penggunaan media seperti, multimedia interaktif memungkinkan siswa untuk meraih hasil belajar $80 \%$ dari yang dipelajarinya. (Suyanto, 2003, p.18).

Berdasarkan hasil observasi di atas, untuk menyiapkan dan menghasilkan lulusan yang berkompeten pada kompetensi ini maka sangat perlu dilakukan pengembangan desain dan model pembelajaran yang inovatif dan interaktif. Pengembangan multimedia pembelajaran interaktif kompetensi dasar pemasangan sistem penerangan dan wiring kelistrikan menjadi salah satu solusi dalam rangka mencapai tujuan pendidikan yang diharapkan yakni meningkatkan kualitas pembelajaran.

Tujuan dari penelitian ini adalah: (1) menghasilkan multimedia pembelajaran interaktif kompetensi dasar pemasangan sistem penerangan dan wiring kelistrikan pada kelas XI SMK bidang keahlian Teknik Kendaraan Ringan; (2) mengetahui kualitas multimedia pembelajaran interaktif; (3) mengetahui efektifitas multimedia pembelajaran interaktif kompetensi dasar pemasangan sistem penerangan dan wiring kelistrikan pada kelas XI SMK bidang keahlian Teknik Kendaraan Ringan.

Multimedia interaktif merupakan kumpulan dari beberapa media seperti tesk, gambar, audio, video, dan animasi yang bersifat interaktif yang digunkan untuk menyampaikan informasi. Ivers \& Ann (2010, p.2) menjelaskan: "multimedia is the use of several media to present information. Combinations may include text, graphics, animation, pictures, video, and sound". Multimedia adalah penggunaan beberapa media untuk menyajikan informasi. Kombinasi ini dapat berisi teks, grafik, animasi, gambar, video, dan suara. Teknologi saat ini, bagaimanapun memungkinkan pendidik dan siswa untuk mengintegrasikan, menggabungkan dan berinteraksi dengan media yang jauh melampaui apa yang sebelumnya. Vaugan (2011, p.1) menjelaskan bahwa: "Multimedia is any combination of text, art, sound, animation, and video delivered to you by computer or other electronic or digitally manipulated means". Multimedia adalah kombinasi teks, seni, suara, animasi, dan video yang dikirimkan oleh komputer atau sarana elektronik lainnya atau digital dimanipulasi.

Munir (2013, pp.3-4) membagi multimedia menjadi beberapa jenis atau kategori, yaitu: multimedia yang berbentuk nertwork-online (internet) dan multimedia offline/stand alone (tradisional). Jenis jasa multimedia terdiri dari dua yaitu berdiri sendiri (offline/stand alone), seperti pengajaran konvensional/tradisional dan terhubung dengan jaringan telekomuniksi (network-online) seperti internet. Sistem multimedia stand alone merupakan sistem komputer multimedia yang memiliki minimal penyimpanan/storage (harddisk, CD-ROM/ DVD-ROM/CD-RW/DVD-RW) alat input (keyboard, mouse, scanner dan mic) dan alat output (speaker, monitor, LCD Proyektor).

Keunggulan yang dimiliki oleh multimedia pembelajaran interaktif sebagai media pembelajaran menurut Newby (2000, p.108), antara lain: (1) memberikan pembelajaran dengan penyimpanan informasi yang baik; (2) desain pembelajaran yang ditunjukan bagi siswa dengan karakteristik belajar yang berbeda; (3) langsung ditujukan bagi domain pembelajaran efektif tertentu; (4) menghadirkan pembelajaran yang realistis; (5) dapat meningkatkan motivasi peserta didik; (6) menuntut siswa agar lebih interaktif; (7) kegiatan pembelajaran lebih bersifat individual; (8) memiliki konsistensi materi yang diberikan; dan (9) siswa mempunyai pengendalian terhadap kecepatan belajar setiap individu.

Vaugan(2011,p.297) menjelaskan terdapat empat struktur dasar navigasi yang digunakan dalam produk multimedia, diantaranya: (1) struktur linier; (2) struktur hierarkis; (3) struktur non linier; dan (4) struktur komposit. dalam penelitian ini peneliti menggunakan struktur hierarkies (linier dengan percabangan) karena sepanjang percabangan-percabangan 
dari struktur ini terbentuk oleh logika isi yang tersedia dari setiap materi.

Kompetensi dasar memasang sistem penerangan dan wiring kelistrikan ini berisikan materi informasi tentang jaringan kabel, saklar pengendali jaringan kelistrikan dan wiring kelistrikan. Kompetensi dasar ini memberikan pengetahuan kepada peserta didik tentang komponen-komponen yang dipakai pada sistem kelistrikan bodi yang meliputi sistem penerangan lampu kepala, lampu kota, sistem lampu belakang, sistem tanda belok dan bahaya (hazard), sistem lampu rem, dan sistem lampu mundur. Kompetensi dasar ini juga menyajikan cara pemasangan sistem kelistrikan bodi sesuai dengan SOP, agar dalam pemasangan tidak menimbulkan kerusakan pada komponen lainnya.

Sistem penerangan (lighting system) sangat diperlukan untuk keselamatan pengendara dimalam hari. Sistem penerangan yang dimaksudkan adalah sistem yang dapat/ harus dioperasikan pada malam hari agar dapat digunakan untuk membantu memudahkan pengemudi mengoperasikan atau menjalankan mobil dengan sempurna. Juga berfungsi memudahkan pengendara lain atau orang lain yang berada di luar kendaraan mengetahui dengan cepat dan jelas bahwa yang terlihat adalah unit kendaraan tertentu (mobil atau sepeda motor). Sistem penerangan adalah salah satu sistem yang menjamin keselamatan dan kenyamanan pengemudi kendaraan terutama pada malam hari. Fungsi utama sistem penerangan ini adalah sebagai penerangan ketika malam atau siang hari dan juga sebagai salah satu isyarat kendaraan untuk memberikan tanda-tanda kepada pengendara lain. Sistem penerangan ini sangat penting bagi kita ketika kita berkendara baik dsiang hari maupun dimalam hari. Gunadi (2011, p.18) dalam bukunya juga menjelaskan sistem penerangan dan wiring kelistrikan merupakan salah satu bagian penting dalam sebuah kendaraan. Selain sistem penerangan juga ada sistem tanda yaitu kelengkapan kendaraan yang digunakan untuk memberi tanda (merubah arah, memperlambat, bahaya) pada kendaraan lain/orang yang berada di luar kendaraan tanpa harus pengemudi menggunakan gerak anggota badannya sebagai suatu tanda. Kedua sistem tersebut di atas harus ada pada setiap kendaraan bermotor serta harus berfungsi secara sempurna karena kedua sistem tersebut dimaksudkan untuk menjamin keamanan dan keselamatan berkendara, maupun orang lain di luar kendaraan.

\section{METODE PENELITIAN}

\section{Jenis Penelitian}

Penelitian ini adalah penelitian dan pengembangan (research and development). Penelitian ini diadaptasi dari Lee \& Owens meliputi 5 tahapan yaitu: (1) analisis; (2) desain produk; (3) pengembangan produk; (4) implementasi; dan (5) evaluasi

\section{Waktu dan Tempat Penelitian}

Penelitian ini dilakukan mulai tanggal 2 juni sampai 17 Juni 2014 di SMK Negeri 2 Depok, Sleman, Yogyakarta.

\section{Subjek Penelitian}

Subjek Validasi produk adalah 2 orang ahli yaitu ahli materi dan ahli media. Sedangkan subjek uji coba produk multimedia pembelajaran interaktif dalam penelitian pengembangan ini adalah siswa kelas XI TKR SMKN 2 Depok. Pengambilan data dibagi sebanyak tiga kali dengan siswa yang berbeda.

\section{Prosedur Penelitian}

Prosedur pengembangan yang dilakukan dalam penelitian pengembangan ini merupakan hasil modifikasi dari prosedur pengembangan menurut Lee \& Owens. Prosedur pengembangan tersebut mempunyai 5 tahap sebagai berikut: : (1) analisis terdiri dari studi lapangan \& analisis kebutuhan pada proses pembelajaran kompetensi dasar pemasangan sistem penerangan dan wiring kelistrikan; (2) desain produk terdiri dari: menentukan spesifikasi media, membuat flowchart, menentukan strategi pembelajaran, menentukan software yang akan digunakan; (3) pengembangan produk; (4) implementasi; dan (5) evaluasi. 


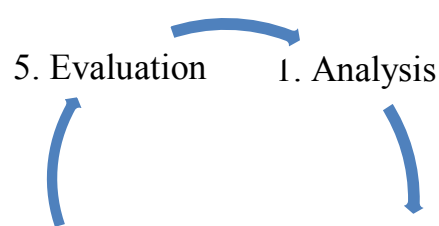

4. Implementation

2. Design

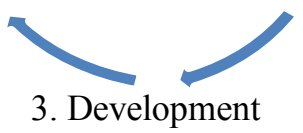

Gambar 1. Prosedur Pengembangan Multimedia Interaktif menurut Lee \& Owens

\section{Desain Uji Coba}

Uji coba merupakan bagian terpenting dalam penelitian pengembangan. Uji coba merupakan bentuk evaluasi formatif yang dilakukan dengan cara meminta penilaian orang lain untuk mencoba produk yang dikembangkan. Responden uji coba biasanya dipilih yang mewakili kelompok sasaran. Uji coba menghasilkan temuan tentang kelemahan, kekurangan, kesalahan produk dan saran-saran. Tujuan uji coba ini adalah untuk mengetahui kualitas dari produk media yang dikembangkan dan apakah multimedia interaktif ini layak atau tidak untuk digunakan.

Setelah produk multimedia pembelajaran interaktif jadi, maka dilakukan uji akhir produk dan memberikan penilaian (judgment) untuk mengetahui efektivitas produk yang dihasilkan. Uji coba efektivitas menggunakan uji dengan membandingkan hasil pretest dengan posttest.

\section{Instrumen Pengumpulan Data}

Instumen angket berupa lembar penilaian dalam bentuk lembar validasi berisi butirbutir penilaian untuk setiap aspek, baik aspek pembelajaran, aspek isi/materi, aspek tampilan maupun aspek pemograman yang akan diisi oleh ahli media, ahli materi, dan subjek uji coba. Sedangkan instrument tes merupakan tes penguasaan materi kompetensi dasar pemasangan sistem penerangan dan wiring kelistrikan ini. Soal tes berjumlah 20 butir soal dalam bentuk pilihan ganda yang mewakili setiap pokok bahasan pada materi utama dalam produk multimedia ini. Tes digunakan untuk menjaring data kuantitatif guna menentukan efektivitas produk penelitian dalam pengembangan ini.

\section{Validasi Instrumen}

Validasi instrumen dalam penelitian ini merupakan validasi instrumen angket yang akan digunakan untuk menilai produk multimedia interaktif yang dikembangkan. Instrument yang divalidasi berupa instrumen angket untuk ahli media, ahli materi dan siswa sebagai pengguna. Instrument angket ini terdiri dari 4 aspek penilaian, yaitu: aspek tampilan, aspek pemograman, aspek pembelajaran dan aspek isi. Selain itu, intrumen tes berupa soal pretest dan posttes juga divalidasi. Intrumen berupa soal pretest dan posttest digunakan untuk mengetahui keefektifan produk multimedia pembelajaran interaktif ini dilihat dari hasil belajar siswa. Seluruh instrumen tersebut diberikan kepada seorang dosen ahli yang ditunjuk sebagai validator untuk memvalidasi instrumen, kemudian hasil dari validasi tersebut dianalisis dan dilakukan perbaikan jika terdapat kesalahan dalam penyusunan instrumen. Setelah instrumen tersebut dinyatakan valid oleh validator selanjutnya instrumen dapat digunakan untuk melakukan penelitian.

\section{Validasi Produk}

Produk multimedia pembelajaran interaktif yang telah dikembangkan selanjutnya akan dinilai dan divalidasi oleh validator ahli. Kriteria penilaian produk multimedia tertuang dalam instrumen angket yang telah divalidasi sebelumnya. Selanjutnya, intrumen angket diisi oleh validator ahli sesuai dengan aspek penilaian masing-masing. Validasi produk multimedia pembelajaran interaktif ini dilakukan oleh satu orang ahli materi dan satu orang ahli media. Validator ahli materi merupakan seseorang ahli yang mengerti tentang materi sistem kelistrikan otomotif, sedangkan validator ahli media merupakan seorang ahli yang mengerti dan menguasai tentang multimedia pembelajaran interaktif. Data penilaian validator ahli materi dan ahli media akan digunakan untuk mengetahui kualitas dari rancangan produk multimedia pembelajaran interaktif ini. Dosen validator memberikan penilaian untuk direvisi sampai produk dinilai layak untuk diuji cobakan ke siswa. 
Tabel 1. Kategori kecenderungan data

\begin{tabular}{lc}
\hline Interval & Kategori \\
\hline$(+1,80 \mathrm{Sbi})<\mathrm{X}$ & Sangat Baik \\
$(+0,60 \mathrm{Sbi})<\mathrm{X} \leq(+1,80 \mathrm{Sbi})$ & Baik \\
$(-0,60 \mathrm{Sbi})<\mathrm{X} \leq(+0,60 \mathrm{Sbi})$ & Cukup \\
$(-1,80 \mathrm{Sbi})<\mathrm{X} \leq(-0,60 \mathrm{Sbi})$ & Kurang \\
$\mathrm{X} \leq(-1,80 \mathrm{Sbi})$ & Sangat Kurang \\
\hline
\end{tabular}

Keterangan:

$\mathrm{i} \quad=1 / 2($ maksimal + skor minimal $)$

$\mathrm{SBi}=1 / 6$ (skor maksimal - skor minimal)

$\mathrm{X} \quad=$ Skor aktual

\section{Teknik Analisis Data}

Data yang diperoleh dari hasil penilaan ahli materi, ahli media, dan subjek uji coba (siswa) dianalisis dengan menggunakna kategori kecenderungan data. Penilaian dilakukan untuk mendapatkan tanggapan tentang kualitas produk yang dikembangkan. Hasil berupa skor dari penilaian tersebut kemudian dikonversikan menjadi nilai, setelah itu dengan menggunakan tabel kecenderungan data untuk menentukan kategori penilaian. Tabel kecenderungan data berdasarkan acuan (dalam Sukarjo 2008: 83), dapat dilihat pada Tabel 1.

\section{Analisis Data Instrument Test}

Analisis data test merupakan analisis data yang diperoleh dari tes hasil belajar siswa setelah mengerjakan soal pretest dan posttets kompetensi dasar pemasangan sistem penerangan dan wiring kelistrikan. Hasil belajar siswa dari pretest dan posttes terlebih dahulu akan dicari jumlahnya dan rata-rata dari tes hasil belajar tersebut. Selanjutnya, data hasil pretest dan posttest ini dianalisis untuk melihat efektifitas penggunaan multimedia pembelajaran interaktif ini terhadap hasil belajar siswa. Rata-rata penilaian menggunakan rumus berikut:

$$
\bar{X}=\frac{\sum X}{n}
$$

(Irianto 2008: 29)

Keterangan:

$$
\begin{array}{ll}
\overline{\mathrm{X}} & =\text { Rata-rata } \\
\mathrm{X} & =\text { Hasil skor (pretes / postes) siswa } \\
\mathrm{n} & =\text { Jumlah siswa }
\end{array}
$$

\section{HASIL DAN PEMBAHASAN}

Sebagaimana prosedur penelitian yang telah dikemukakan pada Bab III, penelitian pengembangan ini terdiri dari 5 (lima) langkah utama, yaitu: analisis, desain produk, pengembangan produk, implentasi produk dan evaluasi produk.

\section{Analisis}

Pengembangan multimedia pembelajaran interaktif kompetensi dasar pemasangan Sistem Penerangan dan Wiring Kelistrikan diawali dengan melakukan analisis. Adapun data yang diperoleh dari studi pendahuluan ini sebagai berikut:

\section{Analisis Lapangan}

Analisis lapangan dilakukan untuk melihat kondisi di lingkungan sekolah secara langsung (observasi). Analisis lapangan dilakukan dengan wawancara dengan pendidik. Hasil dari analisis lapangan antara lain: (1) pembelajaran sistem penerangan dianggap sebagai salah satu pelajaran yang rumit untuk dipahami oleh peserta didik; (2) kurangnya semangat siswa dalam mengikuti pembelajaran pada materi sistem penerangan karena penyampaian materinya hanya disampaikan oleh guru dengan menggunakan media buku dan papan tulis; (3) pendidik hanya mengandalkan variasi metode mengajar yaitu ceramah, deminstrasi dan diskusi; (4) pendidik mengalami kesulitan dalam hal penyampaian materi sistem penerangan; (5) laboratorium komputer yang terdapat di sekolah belum difungsikan secara optimal; (6) guru kesulitan dalam 
mendapatkan media yang sesuai dengan materi karena media yang ada merupakan media yang lama dan guru mempunyai keinginan untuk mengembangkan media interaktif tetapi mempunyai keterbatasan dalam kemampuan; (7) guru membutuhkan media yang sesuai dengan kondisi sekarang, yang bersifat dapat menarik perhatian siswa dan yang bersifat interaktif; (8) guru dan siswa membutuhkan salah satu media yaitu multimedia interaktif sehingga dapat menunjang proses pembelajaran yang ada dalam materi pada media buku.

\section{Analisis Kebutuhan}

Analisis kebutuhan pengembangan dilakukan untuk mendapatkan informasi tentang sejauh mana pengembangan multimedia interaktif kompetensi dasar pemasangan sistem penerangan dan wiring kelistrikan dibutuhkan dalam mengoptimalkan pelaksanaan proses pembelajaran dan hasil belajar sistem penerangan maupun mata pelajaran lain yang terkait. Data pada langkah pertama diambil dari hasil observasi dan hasil wawancara dengan guru yang mengajar mata pelajaran kelistrikan bodi otomotif ini. Data hasil langkah pertama ini berupa kebutuhan lapangan akan media pembelajaran pada kompetensi dasar pemasangan sistem penerangan dan wiring kelistrikan.

Analisis kebutuhan peserta didik menunjukan beberapa pendapat dan komentar siswa tentang proses pembelajaran kompetensi pemasangan sistem penerangan dan wiring kelistrikan ini. Siswa berpendapat bahwa mereka belum banyak mendapatkan pengalaman belajar yang lebih bervariasi. Metode pembelajaran yang lebih sering digunakan oleh guru dalam menyampaikan meteri pelajaran adalah ceramah dan diskusi saja. Penggunaan media pembelajaran dalam penyampaian materi pada kompetensi sistem pemasangan sistem penerangan dan wiring kelistrikan masih sangat kurang. Terkadang guru menggunakan media ketika menyampaikan materi tetapi belum membuat perhatian siswa meningkat karena media yang digunakan hanya dalam bentuk powerpoint saja belum bersifat interaktif. Siswa kesulitan dalam menyerap materi yang disampaikan oleh guru padahal siswa harus benar-benar paham dengan materi yang disampaikan karena setelah selesai materi mereka akan melanjutkan praktek.

Analisis kebutuhan guru juga menjelaskan proses pembelajaran kompetensi dasar pemasangan sistem penerangan dan wiring kelistrikan yang terjadi di kelas. Pendapat siswa-siswa yang mengalami masalah dalam proses pembelajaran sistem penerangan dan wiring kelistrikan di atas juga diaminin oleh guru yang memgampu mata pelajaran kelistrikan ini. Guru juga menyebutkan bahwa dia mengalami kesulitan dalam membuat media pembelajaran yang berbentuk interaktif sehingga ketika ada simulasi aliran arus guru hanya bisa menggambarkan dan menjelaskan di papan tulis atau lewat gambar yang tersedia di buku saja. Hal ini membuat banyak waktu yang terbuang dan sebagian siswa masih ada yang kurang paham dengan penjelasan guru, apalagi dengan siswa yang duduk di bagian belakang. Kondisi ini tentunya bertolak belakang dengan isu optimalisasi pemanfaatan teknologi informasi dan komunikasi yang saat ini sedang bekembang di lingkungan sekolah menengah kejuruan.

\section{Desain Produk}

Hasil yang diperoleh dari tahap desain adalah: materi pada multimedia pembelajaran interaktif dalam penelitian ini terdapat pada kompetensi dasar pemasangan sistem penerangan dan wiring kelistrikan. Flowchart merupakan diagram alur dalam pembuatan multimedia pembelajaran interaktif ini.

Selanjutnya, pembuatan storyboard yang akan digunakan untuk menggambarkan bentuk setiap tampilan dalam setiap frame dalam multimedia yang dikembangkan. Srategi pembelajaran yang akan digunakan dalam multimedia interaktif antara lain: (1) strategi pembelajaran yang diterapkan dalam produk multimedia yang dikembangkan ini meliputi: (a) urutan pembelajaran, yaitu pendahuluan berupa petunjuk penggunaan kompetensi dan kompetensi yang diharapkan, penyajian berupa uraian materi lengkap disertai dengan contoh dan penutup berupa latihan soal untuk mengetahui tingkat pemahaman siswa berdasarkan materi yang dipelajari; (b) metode 
pembelajaran yang digunkaan cenderung pada metode pembelajarana individual karena siswa dihadapkan dengan komputer masing-masing dan penerapan teori belajar tuntas; (2) materi yang digunakan dalam produk multimedia interaktif ini adalah materi sistem penerangan luar; (3) bentuk penilaian yang digunakan dalam pembelajaran yang menggunakan produk multimedia interaktif ini adalah tes hasil belajar. Tes ini digunakan untuk mengukur tingkat kemampuan pemahaman dan ketuntasan siswa dalam penguasaan materi ini.

\section{Pengembangan Produk}

Pengembangan produk multimedia pembelajaran interaktif secara keseluruhan membahas tentang materi sistem penerangan luar. Proses produksi media ini juga didasarkan pada rancangan prototype, flowchart, dan storyboard yang sudah dibuat sebelumnya serta bahan-bahan pendukung pembuatan produk yang lainya. Target pengguna produk multimedia pembelajaran interaktif ini yaitu siswa SMK kelas XI bidang keahlian Teknik Kendaraan Ringan. Multimedia ini dikemas dalam dua bentuk penyimpanan yaitu dalam bentuk Compact Disc (CD) dan Flashdisc. Semua bahan yang telah disiapkan pada tahap sebelumnya disatukan untuk membuat multimedia pembelajaran yang bersifat interaktif dengan menggunakan program Adobe flash CS3 dengan program action script 2.0.

Produk awal yang telah selesai dikembangkan terlebih dahulu dilakukan pengecekan sebelum produk awal divalidasi dan diuji cobakan kepada peserta didik. Pengecekan dilakukan secara internal yaitu dimulai dengan pengecekan jalannya program secara keseluruhan. Secara garis besar produk multimedia pembelajaran interaktif hasil pengembangan pada tahap awal ini berisi: (1) petunjuk penggunaan, berfungsi untuk memberitahu pengguna cara menggunakan multimedia inetraktif ini; (2) kompetensi, yang berisi rumusan standar kompetensi, kompetensi dasar, indikator dan tujuan pembelajaran; (3) materi, terdiri dari 2 menu materi, materi yang pertama terdiri dari pengertian, bagian, komponen pendukung dan cara kerja sistem penerangan; (4) materi kedua/materi simulasi terdiri dari simulasi atau animasi dari cara kerja dari sistem penerangan ini; (5) evaluasi, berisi latihan soal-soal matesi sitem penerangan luar yang telah dipelajari. Latihan ini berfungsi untuk mengecek tingkat pemahaman siswa tentang materi yang sedang mereka pelajari; (6) Games, yaitu beberapa permainan yang berhubungan dengan materi yang berfungsi untuk melihat pemahaman siswa juga terhadap materi yang ada; (7) profil, yaitu berisi profil pengembang, profil dosen pembimbing, profil ahli media, dan profil ahli materi.

\section{Implementasi Produk}

Produk multimedia pembelajaran interaktif yang dinyatakan layak oleh para ahli selanjutnya akan diimplementasikan/ diuji cobakan kepada siswa SMK Negeri 2 Depok kelas XI program keahlian Teknik Kendaraan Ringan (TKR). Implementasi/uji coba ini dilakukan oleh 32 siswa yang terdiri dari beberapa tahap yaitu: (1) tahap pertama dengan 3 siswa yang disebut uji coba individu; (2) tahap kedua dengan 9 siswa yang disebut uji coba terbatas; (3) tahap ketiga dengan 20 orang siswa yang disebut uji coba lapangan.

\section{Evaluasi Produk}

Produk dinyatakan layak oleh para ahli kemudian diimplementasikan dan dinilai oleh siswa dalam bentuk ujicoba. Uji coba produk multimedia pembelajaran interaktif pada setiap tahap akan dinilai oleh siswa dan direvisi berdasarkan kekurangan yang ada dalam multimedia tersebut. Saran dan kritik dari siswa yang diberikan pada setiap uji coba juga akan direvisi untuk menyempurnakan multimedia pembelajaran interaktif ini. Uji coba tersebut terdiri dari: (1) uji coba individu dilakukan oleh 3 orang siswa dan mereka memberikan penilaian untuk kemudian hasil dari penilaian pada tahap pertama akan dianalisis untuk menjadi bahar revisi; (2) uji coba terbatas dilakukan oleh 9 orang siswa yang kemudian juga memberikan penilaian tentang produk yang dikembangkan dan kemudian produk multimedia direvisi kembali; (3) setelah direvisi dilakukan uji coba lapangan yang dilakukan oleh 20 orang siswa. Hasil penilaian dari uji coba lapangan akan direvisi akhir untuk menjadi produk akhir. 
Tabel 2.Hasil penilaian ahli materi dan media

\begin{tabular}{clccc}
\hline No & Aspek & Jumlah & $\mathbf{( \% )}$ & Kriteria \\
\hline 1 & Tampilan & 97 & 36,33 & Sangat baik \\
2 & Pemograman & 50 & 18,73 & Baik \\
3 & Pembelajaran & 66 & 24,72 & Baik \\
4 & Isi/materi & 54 & 20,22 & Baik \\
\hline Total & 267 & & Baik \\
\hline
\end{tabular}

Tabel 3. Hasil penilaian uji coba individu.

\begin{tabular}{clccc}
\hline No & Aspek & Jumlah & $\mathbf{( \% )}$ & Kriteria \\
\hline 1 & Tampilan & 227 & 34,45 & Baik \\
2 & Pemograman & 74 & 11,23 & Baik \\
3 & Pembelajaran & 189 & 28,68 & Baik \\
4 & Isi/materi & 169 & 25,64 & Baik \\
\hline Total & 659 & & Baik \\
\hline
\end{tabular}

\section{Analisis Hasil Penelitian}

Hasil yang diperoleh dalam penelitian ini terdiri dari data penilaian ahli materi dan ahli media, data penilaian guru mata pelajaran, data respons siswa, dan pre-test dan post-test. Data hasil penilaian produk ini meliputi data hasil validasi dari ahli materi dan ahli media, serta data evaluasi siswa.

\section{Validasi Ahli}

Dalam analisis data hasil validasi produk ahli materi dan ahli media terdapat empat aspek yang menjadi penilaian ahli media dan ahli materi yaitu aspek tampilan, pemograman, pembelajaran dan materi. Berdasarkan hasil validasi ahli media dan ahli materi disimpulkan kualitas multimedia interaktif yang dikembangkan ditinjau dari aspek tampilan adalah sangat baik, ditinjau dari aspek pemograman adalah baik, ditinjau dari aspek pembelajaran adalah baik serta ditinjau dari aspek isi/materi adalah baik. Berikut ini data hasil penilaian pengembangan multimedia interaktif: (Tabel 2)

Secara visual penilaian ahli dalam pengembangan multimedia pembelajaran interaktif materi sistem penerangan yang dapat dilihat pada gambar 2 .

Hasil penilaian secara keseluruhan aspek pada validasi ahli menunjukan bahwa multimedia pembelajaran interaktif memiliki kriteria "baik".

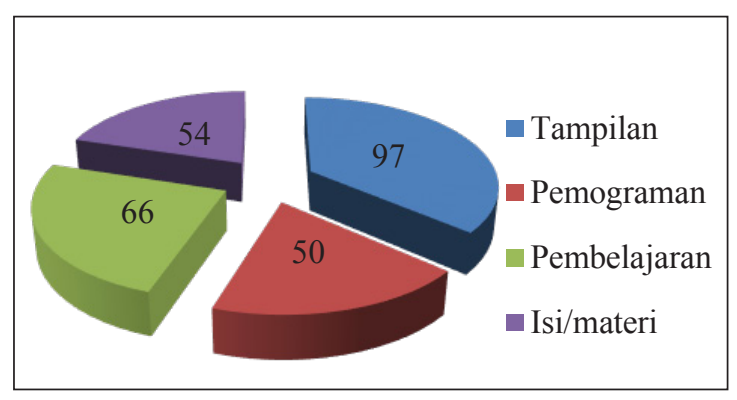

Gambar 2. Diagram penilaian ahli

\section{Uji Coba Individu}

Hasil uji coba individu disimpulkan bahwa kualitas multimedia interaktif yang dikembangkan ditinjau dari aspek tampilan adalah baik, ditinjau dari aspek pemograman adalah sangat baik, ditinjau dari aspek pembelajaran adalah baik serta ditinjua dari aspek isi/materi adalah baik. Berikut ini data perbandingan aspek penilaian pengembangan multimedia interaktif pembelajaran materi sistem penerangan untuk uji coba individu yang dapat dilihat pada Tabel 3 .

Secara visual perbandingan keempat aspek penilaian pengembangan multimedia pembelajaran interaktif materi sistem penerangan untuk uji coba individu dapat dilihat pada gambar 3 .

Hasil penilaian secara keseluruhan aspek pada uji coba satu-sat menunjukan bahwa multimedia pembelajaran interaktif memiliki kriteria "baik". 
Tabel 4. Hasil penilaian uji coba terbatas

\begin{tabular}{clccc}
\hline No & Aspek & Jumlah & $\mathbf{( \% )}$ & Kriteria \\
\hline 1 & Tampilan & 690 & 28.34 & Sangat baik \\
2 & Pemograman & 227 & 26.06 & Baik \\
3 & Pembelajaran & 570 & 34.31 & Sangat baik \\
4 & Isi/materi & 524 & 11.29 & Baik \\
\hline Total & 2011 & & Sangat baik \\
\hline
\end{tabular}

Tabel 5. Hasil penilaian uji coba lapangan

\begin{tabular}{clccc}
\hline No & Aspek & Jumlah & $\mathbf{( \% )}$ & Kriteria \\
\hline 1 & Tampilan & 1562 & 28.05 & Sangat baik \\
2 & Pemograman & 519 & 26.25 & Sangat baik \\
3 & Pembelajaran & 1277 & 34.31 & Sangat baik \\
4 & Isi/materi & 1195 & 11.40 & Sangat baik \\
\hline Total & 4553 & & Sangat baik \\
\hline
\end{tabular}

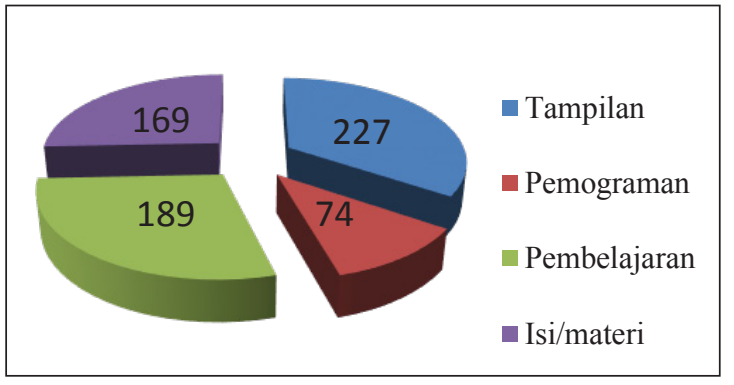

Gambar 3. Diagram penilaian uji coba individu

\section{Uji Coba Terbatas}

Hasil uji coba terbatas tersebut, dapat disimpulkan bahwa kualitas multimedia interaktif yang dikembangkan ditinjau dari aspek tampilan adalah sangat baik, ditinjau dari aspek pemograman adalah sangat baik, ditinjau dari aspek pembelajaran adalah baik serta ditinjau dari aspek isi/materi adalah baik. Berikut ini data hasil penilaian pengembangan multimedia interaktif materi sistem penerangan untuk uji coba terbatas dilihat pada Tabel 4.

Secara visual hasil penilaian pengembangan multimedia pembelajaran interaktif materi sistem penerangan untuk uji coba terbatas yang dapat dilihat pada Gambar 4.

Hasil analisis di atas dapat disimpulkan bahwa kualitas media interaktif yang dikembangkan ditinjau dari aspek tampilan, aspek pemogaman, aspek pembelajaran dan aspek isi/materi dinilai sangat baik.

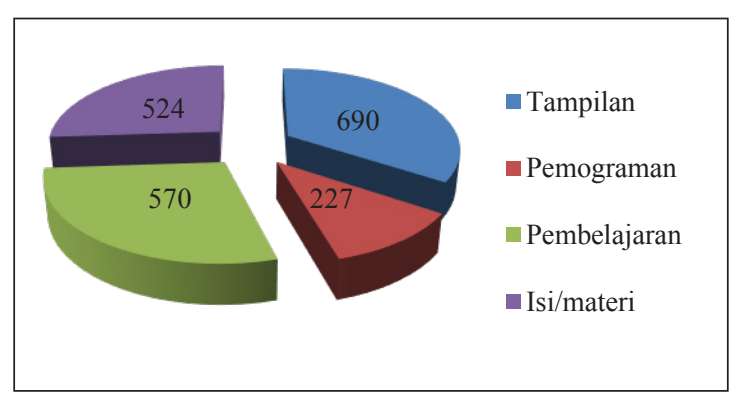

Gambar 4. Diagram penilaian uji coba terbatas.

\section{Uji Coba Lapangan}

Hasil uji coba lapangan dapat disimpulkan bahwa kualitas multimedia interaktif yang dikembangkan ditinjau dari aspek tampilan adalah sangat baik, ditinjau dari aspek pemograman adalah sangat baik, ditinjau dari aspek pembelajaran adalah baik, dan ditinjau dari aspek isi/materi adalah baik. Berikut ini data hasil penilaian produk multimedia interaktif pembelajaran materi sistem penerangan pada uji coba lapangan:

Secara visual hasil penilaian produk multimedia pembelajaran interaktif materi sistem penerangan untuk uji coba lapangan dapat dilihat pada gambar 5 .

Hasil penilaian di atas dapat disimpulkan bahwa kualitas produk multimedia pembelajaran interaktif yang dikembangkan ditinjau dari aspek tampilan, aspek pemrogaman, aspek pembelajaran dan aspek isi/materi dinilai 
Tabel 6. Hasil penilaian preteset dan posttest

\begin{tabular}{lcccc}
\hline \multirow{2}{*}{ Kategori } & \multicolumn{2}{c}{ Jumlah benar } & \multicolumn{2}{c}{ Nilai } \\
\cline { 2 - 5 } & Pretest & Posttest & Pretest & Posttest \\
\hline Nilai terendah & 10 & 13 & 50 & 65 \\
Nilai tertinggi & 15 & 18 & 75 & 90 \\
Jumlah & 255 & 315 & 1275 & 1575 \\
Rata-rata & 12.75 & 15.75 & 63,75 & 78,75 \\
\hline
\end{tabular}

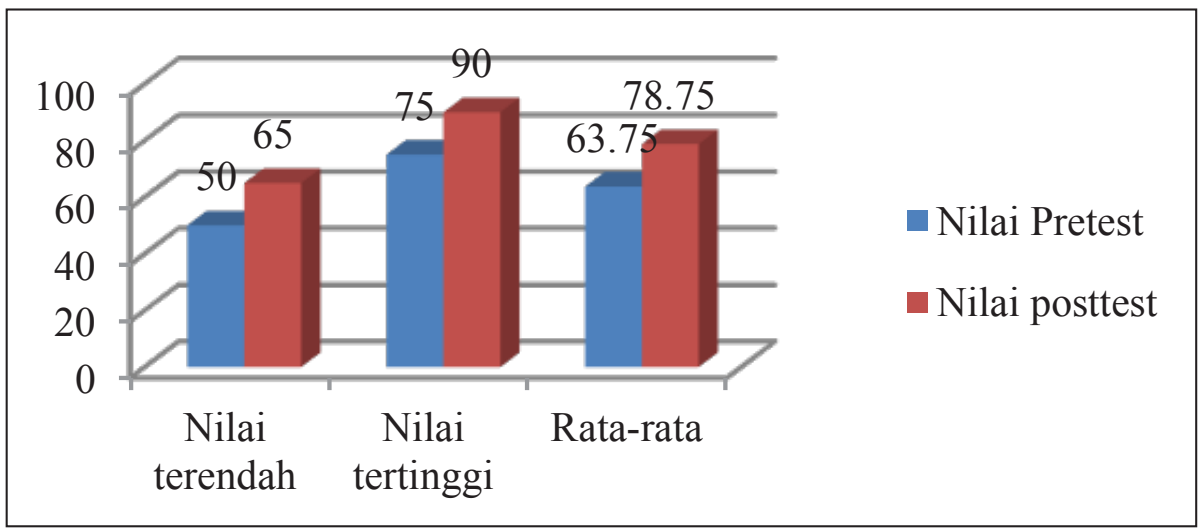

Gambar 6. Perbandingan hasil penilaian pretes dengan posttest

sangat baik. Sehingga, secara keseluruhan yang dinilai dari hasil uji coba lapangan termasuk dalam kriteria sangat baik. Untuk itu produk multimedia yang ini dapat digunakan dan dinyatakan sebagai produk final.

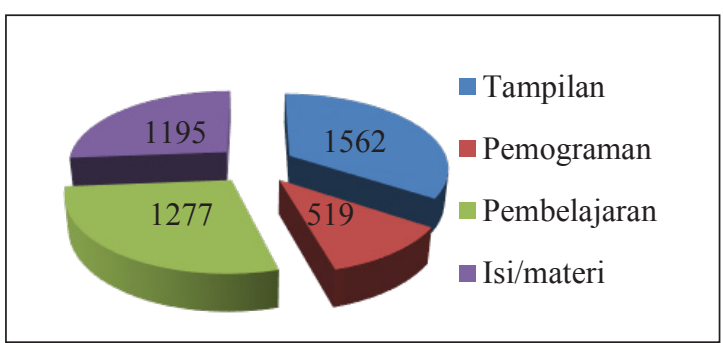

Gambar 5. Diagram penilaian uji coba lapangan.

\section{Pretest dan Posttest}

Berdasarkan hasil pretest didapatkan hasil sebagai berikut: 1 siswa mendapatkan nilai 50, 3siswa mendapatkan nilai 55 , 6 siswa mendapatkan nilai 60,3 siswa mendapatkan nilai 65,4 siswa mendapatkan nilai 70, dan 3 siswa mendapatkan nilai 75 . Sedangkan pada hasil penilaian postest 2 siswa mendapatkan nilai 65,1 siswa mendapatkan nilai 70,6 siswa yang mandapatkan nilai 75 , 4 siswa yang mendapatkan nilai 80,5 siswa yang mendapatkan nilai 85 , dan 2 siswa mendapatkan nilai 90. Data hasil penilaian pretest dan posttest dapat dilihat pada tabel 6 .

Secara visual perbandingan hasil penilaian pretest dengan posstest pada pengembangan multimedia pembelajaran interaktif materi sistem penerangan yang dapat dilihat pada gambar 6.

Berdasarkan tabel 6 diketahui bahwa terdapat peningkatan hasil belajar siswa setelah menggunakan produk multimedia pembelajaran interaktif ini. Produk multimedia pembelajaran interaktif kompetensi dasar pemasangan sistem penerangan dan wiring kelistrikan sangat efektif untuk meningkatkan hasil belajar siswa. Rata-rata penilaian hasil belajar siswa yang didapat ketika pretest adalah 63,75 dengan nilai terendah yang didapat siswa sebesar 50 dan nilai tertinggi sebesar 75 . Sedangkan rata-rata nilai posttest sebesar 78,75 dengan nilai terendah 65 dan nilai tertinggi 
90. Sehingga dapat disimpulkan bahwa penggunaan produk multimedia pembelajaran interaktif kompetensi dasar pemasangan sistem penerangan dan wiring kelistrikan ini efektif untuk meningkatkan hasil belajar siswa.

Produk multimedia pembelajaran interaktif kompetensi dasar pemasangan sistem penerangan dan wiring kelistrikan materi sistem penerangan luar menggunakan teknologi Adobe Flash CS3 dengan Action Script 2,0. Produk multimedia pembelajaran interaktif ini juga didukung oleh program seperti Corel Draw X4 untuk membuat beberapa gambar yang terdapat dalam materi sistem penerangan ini. Pembelajaran menggunakan multimedia pembelajaran interaktif yang dikembangkan ini membuat siswa merasa lebih senang, lebih termotivasi untuk belajar, dan lebih interaktif sesuai dengan kecepatan pemahaman siswa dalam rangka pembelajaran mandiri.

Multimedia pembelajaran interaktif ini juga telah selesai melalui tahap validasi yang dilakukan oleh ahli media dan ahli materi, serta telah mengikuti tahap-tahap dalam pengembangan dengan mengadopsi model pengembangan multimedia pembelajaran interaktif yang dikembangkan oleh Lee \& Owens. Selainvalidasiahlimateridanahlimedia, pengembangan multimedia pembelajaran interaktif ini juga dinilai oleh siswa yang dilakukan pada tahap uji coba individu, uji coba terbatas, dan uji coba lapangan. Setelah dilakukan validasi dan uji coba, multimedia pembelajaran interaktif pemasangan sistem pemasangan dan wiring kelistrikan ini terbukti bahwa mempunyai kemampuan meningkatkan prestasi siswa. Dari hasil pre-test dan posttest terjadi peningkatan nilai atau peningkatan penguasaan keterampilan siswa terhadap materi sistem penerangan luar. Peningkatan nilai ini merupakan efek dari treatment yang dilakukan yakni dengan melihat selisih antara hasil pre-test dengan hasil post-test. Hal demikian karena objek yang digunakan untuk treatment didukung dengan adanya simulasi, gambar, video, suara dan musik yang dapat ditampilkan lewat komputer.

Secara umum kualitas produk multimedia pembelajaran interaktif kompetensi dasar pemasangan sistem penerangan dan wiring kelistrikan yang dikembangkan dapat digolongkan bagus atau baik. Ini terungkap dari hasil penilaian para ahli dan hasil penilaian siswa serta komentar yang disampaikan. Aspek penilaian dari pengembangan multimedia pembelajaran interaktif ini meliputi beberapa aspek, yaitu: aspek tampilan, aspek pemograman, aspek pembelajaran dan aspek isi. Hasil dari penilaian secara keseluruhan aspek tersebut pada uji coba lapangan menunjukan bahwa pada aspek tampilan diperoleh penilaian sebesar 1562 dengan kriteria Sangat Baik, pada aspek pemograman diperoleh penilaian sebesar 519 dengan kriteria sangat baik, pada aspek pembelajaran diperoleh penilaian sebesar 1277 dengan kriteria Sangat Baik, dan pada aspek isi/materi diperoleh penilaian sebesar 1195 dengan kriteria Sangat Baik, sedangkan tes hasil belajar terbukti penggunaan multimedia interaktif mampu meningkatkan hasil belajar siswa. Berdasarkan penilaian tes hasil belajar diketahui bahwa terdapat peningkatan hasil belajar siswa setelah menggunakan produk multimedia pembelajaran interaktif ini. Produk multimedia pembelajaran interaktif kompetensi dasar pemasangan sistem penerangan dan wiring kelistrikan sangat efektif untuk meningkatkan hasil belajar siswa. Rata-rata penilaian hasil belajar siswa yang didapat ketika pretest adalah 63,75 dengan nilai terendah yang didapat siswa sebesar 50 dan nilai tertinggi sebesar 75 . Sedangkan rata-rata nilai posttest sebesar 78,75 dengan nilai terendah 65 dan nilai tertinggi 90. Sehingga dapat disimpulkan bahwa penggunaan produk multimedia pembelajaran interaktif kompetensi dasar pemasangan sistem penerangan dan wiring kelistrikan ini efektif untuk meningkatkan hasil belajar siswa.

Keunggulannya adalah bahwa pembuatan produk multimedia pembelajaran ini menggunakan program Adobe Flash CS3 sehingga menghasilkan file yang tidak terlalu besar kapasitasnya. Kelebihannya adalah program ini memuat gambar-gambar dan juga simulasi sehingga siswa lebih mudah memahami materi tentang sistem penerangan luar ini. Adanya sajian simulasi yang bervariasi membuat multimedia pembelajaran interaktif yang dikembangkan ini menarik dan disenangi oleh siswa. Selain tampilan yang menarik, dalam setiap sub pokok bahasan terutama pada materi 
cara kerja/simulasi multimedia pembelajaran interaktif ini menampilkan simulasi yang jelas. Produk multimedia interaktif ini juga dilengkapi dengan adanya umpan balik langsung ketika siswa mengerjakan latihan soal dan juga ketika siswa mengerjakan game yang ada pada multimedia pembelajaran interaktif ini. Umpan balik yang ada dalam multimedia pembelajaran interaktif ini adalah hasil (nilai) dari pengerjaan soal dan juga berupa penguatan yang berbentuk posistif ketika siswa selesai mengerjakan permainan yang ada.

Produk hasil pengembangan multimedia pembelajaran interaktif sistem penerangan dan wiring kelistrikan ini memiliki kelemahan dan keterbatasan. Beberapa kelemahan tersebut antara lain yaitu, produk multimedia pembelajaran ini hanya dapat digunakan pada sekolah-sekolah yang sudah mempunyai komputerdalamkegiatan pembelajaran, sekolah juga harus mempunyai listrik mencukupi, dan sarana lainnya yang mendukung penggunaan produk ini seperti adanya software lain yang mendukung produk ini agar berjalan dengan baik. Walaupun bukan merupakan sumber belajar yang utama, namun dengan penggunaan produk multimedia pembelajaran berbantuan komputer ini diharapkan dapat membantu memecahkan masalah belajar, baik sebagai sumber belajar alternatif maupun pelengkap. Dengan produk multimedia pembelajaran interaktif ini diharapkan proses pembelajaran pada materi sistem penerangan luar ini akan lebih menarik dan menimbulkan motivasi belajar siswa sehingga dapat meningkatkan keterampilan serta prestasi belajar siswa.

\section{SIMPULAN DAN SARAN}

\section{Simpulan}

Produk yang dihasilkan berupa software multimedia pembelajaran interaktif kompetensi dasar pemasangan sistem penerangan dan wiring kelistrikan materi sistem penerangan luar pada kelas XI SMK bidang keahlian Teknik Kendaraan Ringan yang layak untuk digunakan dalam proses pembelajaran.

Kualitas produk multimedia pembelajara interaktif ini sangat baik. Hasil penilaian ahli media dan ahli materi tentang kelayakan multimedia pembelajaran interaktif kompetensi dasar pemasangan sistem penerangan dan wiring kelistrikan ditinjau dari aspek tampilan sebesar 97 kriteria baik, aspek program 50 kriteria baik, aspek pembelajaran sebesar 66 kriteria baik, dan aspek materi sebesar 54 kriteria baik. Sedangkan hasil penialaian peserta didik uji lapangan pada aspek pembelajaran sebesar 1277 kriteria "sangat baik", pada aspek isi sebesar 1195 dengan kriteria "sangat baik", pada aspek tampilan sebesar 1562 kriteria "sangat baik", dan pada aspek pemograman sebesar 519 kriteria "sangat baik".

Produk multimedia pembelajaran interaktif kompetensi dasar pemasangan sistem penerangan dan wiring kelistrikan sangat efektif untuk meningkatkan hasil belajar siswa. Rata-rata penilaian hasil belajar siswa yang didapat ketika pretest adalah 63,75 dengan nilai terendah yang didapat siswa sebesar 50 dan nilai tertinggi sebesar 75 . Sedangkan ratarata nilai posttest sebesar 78,75 dengan nilai terendah 65 dan nilai tertinggi 90 .

\section{Saran Pemanfaatan Produk}

Multimedia pembelajaran interaktif pada kompetensi dasarmemasang sistem penerangan dan wiring kelistrikan ini efektif digunakan dalam proses pembelajaran, oleh karena itu guru dapat membuat bahan pembelajaran yang menggunakan teknologi komputer untuk mencapai tujuan pembelajaran.

Dari hasil uji coba menyatakan bahwa multimedia pembelajaran interaktif pada kompetensi dasar memasang sistem penerangan dan wiring kelistrikan materi pokok sistem penerangan luar dapat meningkatkan hasil belajar siswa. Untuk itu perlu adanya penggunaan multimedia pembelajaran interaktif sehingga dapat meningkatkan hasil belajar siswa.

Melihat dari antusias siswa dalam menggunakan multimedia pembelajaran interaktif ini cukup tinggi diharapkan pihak sekolah mampu memfasilitasi pengembangan media pembelajaran dengan melengkapi sarana komputer dan pengadakan pelatihan pengembangan multimedia pembelajaran interaktif dilingkungan sekolah. 


\section{DAFTAR PUSTAKA}

Firdausi, Arif \& Barnawi. (2012). Profil guru SMK professional. Yogyakarta: Ar-Ruzz Media

Gunadi. (2011). Sistem kelistrikan bodi. Yogyakarta: Mentari Pustaka

Ivers, K. S. \& Ann E. B. (2002). Multimedia projects in education : designing, producing, and assessing. Second Edition. California : LIBRARIES UNLIMITED Teacher Ideas Press.

Irianto, Agus. (2008). Statistik konsep dasar dan aplikasinya. Jakarta: kencana Prenada Media Group.

Lee, W. W., \& Diana L. O. (2004). Multimedia-based instructional design: computer-based training, web-based training, distance broadcast training, performance-based solutions, Second Edition. San Francisco, CA: John Wiley \& Sons, Inc
Munir. (2013). Multimedia konsep dan aplikasi dalam pendidikan. Bandung: Alfabeta

Newby, T. J., et. al. (2000). Instructional technology for teaching and learning. New Jersey: Prentice-Hall Inc

Sukardjo. 2008. Penilaian hasil belajar kimia. diktat mata kuliah penilaian hasil belajar kimia, Yogyakarta: PPs-UNY

Suyanto, M. (2003). Multimedia: alat untuk meningkatkan keunggulan bersaing. Yogyakarta: percetaan Andi

Vaugan, T. (2011) Multimedia: making it work. Eighth Edition. New York: Technology Education Mac Graw Hill.

Winarno, et. al. (2003) Teknik evaluasi multimedia pembelajaran. Genius prima media. 